\title{
TITLE:
}

\section{PLANKTONIC FORAMINIFERA OF THE ANTARCTIC OCEAN}

$\operatorname{AUTHOR}(\mathrm{S})$ :

Uchio, Takayasu

CITATION:

Uchio, Takayasu. PLANKTONIC FORAMINIFERA OF THE ANTARCTIC

OCEAN. SPECIAL PUBLICATIONS FROM THE SETO MARINE BIOLOGICAL LABORATORY 1960, 1(11): 1-10

\section{ISSUE DATE:}

1960-05

URL:

http://hdl.handle.net/2433/176441

RIGHT: 
SPECIAL PUBLICATIONS FROM THE SETO MARINE BIOLOGICAL LABORATORY

BIOLOGICAL RESULTS
OF

THE JAPANESE ANTARCTIC RESEARCH EXPEDITION

11.

\title{
PLANKTONIC FORAMINIFERA OF THE ANTARCTIC OCEAN
}

\author{
BY \\ TAINAYASU UCHIO \\ PETROLEUM ENGINEERING INSTITUTE \\ UNIVERSITY OF TOKYO \\ BUIKYO-KU, IOKYO, JAPAN
}

SIRAHAMA, WAKAYAMA-KEN

JAPAN

MAY 1960 
SPECIAL PUBLICATIONS FROM THE SETO MARINE BIOLOGICAL LABORATORY

BIOLOGICAL RESULTS

$\mathrm{OF}$

THE JAPANESE ANTARCTIC RESEARCH EXPEDITION

11.

\title{
PLANKTONIC FORAMINIFERA OF THE ANTARCTIC OCEAN
}

BY

\author{
TAKAYASU UCHIO \\ PETROLEUM ENGINEERING INSTITUTE \\ UNIVERSITY OF TOKYO \\ BUNKYO-KU, TOKYO, JAPAN
}

SIRAHAMA, WAKAYAMA-KEN

J A P A N

M A Y 1960 
THIS SERIES contains THE BIOLOGICAL RESULTS OF THE JAPANESE ANTARCTIC RESEARCH EXPEDITION and is published by the Seto Marine Biological Laboratory. Parts will appear at irregular intervals as they become ready.

PRINTED IN JA.PAN

BY NIPPON PRINTING AND PUBLISHING Co., Ltd.

HUKUSIMA, OSAKA 


\section{INTRODUCTION}

THE material here studied was collected by the members of the Second Japanese Antarctic Research Expedition, 1957-58, and comprises two series ; (1) two plankton-net samples collected by Dr. Riozo Yosil, (2) eleven bottom samples collected by Dr. Daitaro SHoJl. The writer wishes to express his cordial thanks to these gentlemen, to Dr. Takasi TokiokA for given the material to the writer and for constant encouragement, and to Dr. Kunio Kigosm for determining $\mathrm{C}^{14}$ dating of the Foraminifera in a sediment sample. Thanks are also due to Dr. Fred B PhLEger and Miss Frances L. PARKER for reading the manuscript.

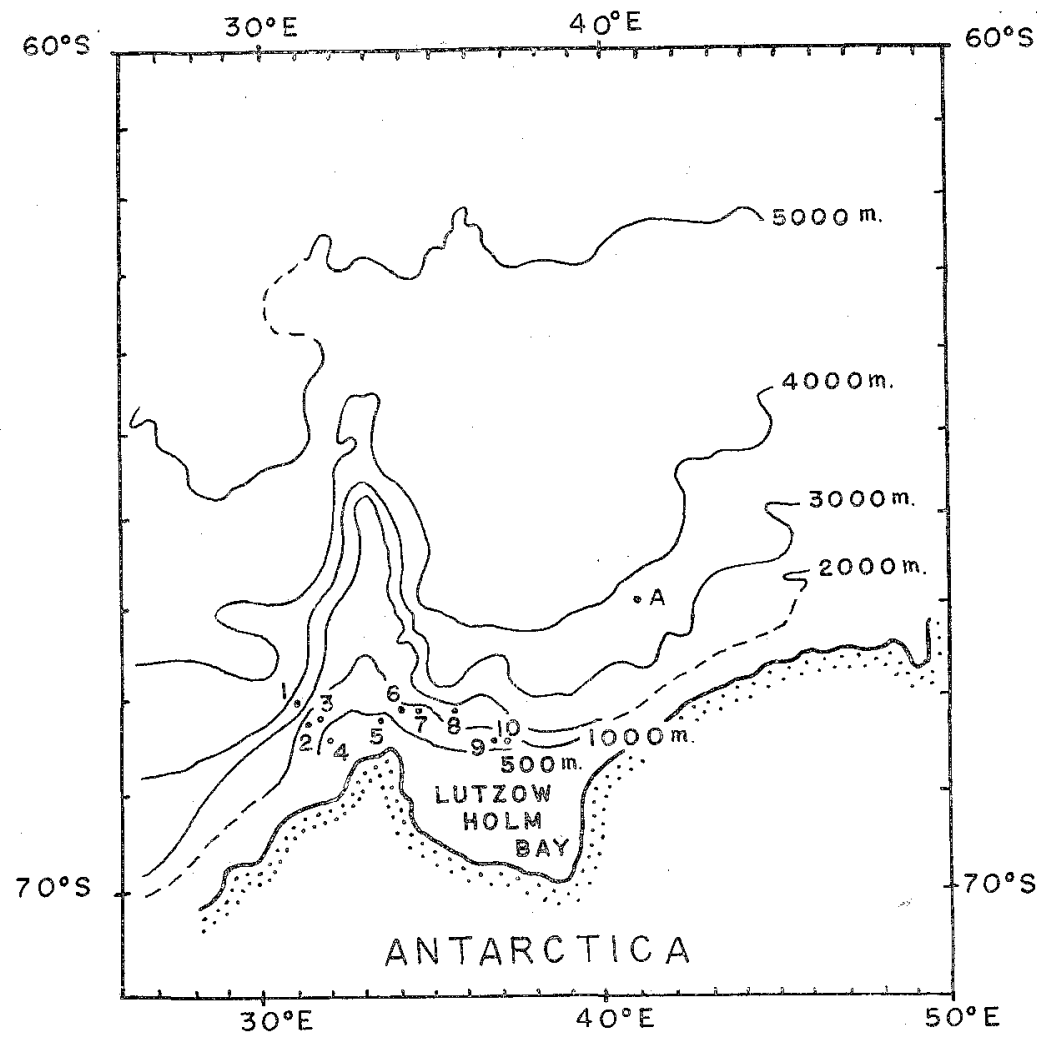

Fig. 1. Locations of stations and the submarine topography.

A : Plankton-net sample.

1-10: Sediment samples. 
The sea around Antarctica is divided into the southern areas of the Atlantic, Pacific and Indian Oceans, comprising what is called the Antarctic Ocean. The Antarctic Ocean is further divided into the Antarctic region and Subantarctic region which are separated by the Antarctic Convergence at about $53^{\circ}$ S. Lat. (Sverdrup et al., 1946, p. 606). One of the plankton-net samples was collected in the Subantarctic region; the other plankton-net sample and all of the bottom samples were collected in the Antarctic region. The locations of these samples are shown in Figure 1. Exact locations of the plankton-net samples are listed in Table 1, but those of the bottom samples will be listed in a separate paper on the benthonic Foraminifera (UchIo, 1960).

Table 1. Location of plankton-net samples.

\begin{tabular}{|c|c|c|c|c|}
\cline { 2 - 5 } Sample & S. Lat. & E. Long. & $\begin{array}{c}\text { Depth (m) of } \\
\text { vertical haul }\end{array}$ & Date of collection \\
\hline A & $66^{\circ} 51^{\prime}$ & $41^{\circ} 19^{\prime}$ & $200-0$ & Dec. 23, 1957 \\
B & $47^{\circ} 41^{\prime}$ & $31^{\circ} 48^{\prime}$ & $50-0$ & Nov. 15, 1957 \\
\hline
\end{tabular}

\section{PLANKTONIC FORAMINIFERA IN PLANKTON-NET SAMPLES}

The plankton-net used has a mouth diameter of $25 \mathrm{~cm}$ and is made of silk grit gauze with effective apertures of $0.5 \mathrm{~mm}$. The water column filtered at stations $A$ and $B$ is from $200 \mathrm{~m}$ and $50 \mathrm{~m}$ to the surface respectively. The volume of water filtered at stations $A$ and $B$ is less than 9800 litres and 2450 litres respectively. The net tows were made in the daytime.

As the samples were preserved in formalin and were not examined until about ten months after collection, the calcareous tests of the Foraminifera in sample B were partly dissolved, very thin and fragile, while those in sample A were completely dissolved leaving only the dark greenish protoplasm, although the shape of the original test was retained. The samples were studied microscopically while they were wet. Sample B contained 1253 specimens of Globigerina sp. cf. G. bulloides D'ORBIGNY and sample A only 74 specimens of the same species. The species here referred to Globigerina sp. cf. G. bulloides D'ORBIGNY is undoubtedly a form which has been called Globigerina bulloides D'ORBIGNY by most. authors but it is slightly different from topotypes of Globigerina bulloides D'ORBIGNY from Recent beach sands at Rimini, Italy. The significance of the finding of this species only in the plankton-net samples is discussed later.

\section{PLANKTONIC FORAMINIFERA IN BOTTOM SEDIMENTS}

The elven sediment samples studied were collected at depths ranging from $350 \mathrm{~m}$ to $2480 \mathrm{~m}$, using a small dredge. The sediments at three stations are 
mud and those at the other stations are sand; the boundary of the two types lies at a depth of approximately $850 \mathrm{~m}$. These sediments contain various kinds and sizes of angular ice-rafted glacial material. Another paper is on the benthonic Foraminifera assemblages in these sediments. A part of the sediment sample at Station 2 was preserved in formalin and the writer, after rose Bengal staining, found eleven species of benthonic Foraminifera which were living when collected, but no living planktonic ones. The other samples were dried after collection and, therefore, the Foraminifera in them were considered to be empty tests, although there might have been some living specimens. All the samples, except the one at Station 8, contain abundant Foraminifera, of which an average of about $82 \%$ are planktonic. Most of the planktonic Foraminifera are Globigerina pachyderma (EHRENBERG) (including "Globigerina dutertrei D'ORBIGNY" of most authors). However, Globigerina sp. cf. G. bulloides D'ORBIGNY is rarely found in all the bottom sediments. The significance of the difference between populations of planktonic Foraminifera in the net samples and those in the bottom samples is discussed later.

\section{IS GLOBIGERINA PACHYDERMA PLANKTONIC OR BENTHONIC?}

In the bottom sediments "Globigerina dutertrei D'ORBIGNY" is dominant and Globigerina pachyderma (EHRENBERG), a relatively small form, takes second place. Morphologically intermediate forms are also found together with typical "Globigerina dutertrei" and Globigerina pachyderma in all the samples. The presence of such intermediate forms together with the two typical forms is also pointed out by PIRIE (1913), HERON-ALLEN \& EARLAND (1922), EARLAND (1933), and OVEY (1950). Therefore, the present writer considers that "Globigerina dutertrei" (G. dutertrei of OVEY, ? BRADY, not D'ORBIGNY) is the adult form of Globigerina pachyderma. The original description and illustration of Globigerina dutertrei D'ORBIGNY are not adequate; BRADY (1884, p. 601) interpreted this species as a typical Antarctic species and most later authors followed his interpretation. As was pointed out by PHLEGER, PARKER \& PEIRSON (1953, p. 13) Globigerina dutertrei, which was originally described by D'ORBIGNY (1839) from Recent marine sands in the vicinity of Cuba and which has thin tests, is unlikely to be conspecific with the Arctic and Antarctic, thick-walled species. BANNER \& BLOW (1960) have recently published a paper in which they designated a lectotype of Globigerina dutertrei D'ORBIGNY. They have included BRADY's form (op. cit., p. 601, pl. 81, figs. $1 \mathrm{a}-\mathrm{c}$ ) as a synonym of the species with some doubt. They also say that Over's form (op. cit., p. 65, pl. 2, figs. $1 \mathrm{a}-\mathrm{c}$ ) is referable to Globorotalia (Turborotalia) and is probably conspecific with the form described by BLow (1959) as $G$. (T.) acostaensis. They have examined the collections of D'ORBIGNY in the Museum National de 
l'Histoire Naturelle, Paris, France, and those of H. B. Brady, Heron-Allen \& EARLAND and other workers in the British Museum (Natural History), London. Yet they have not mentioned BRADY's specimens of his Globigerina dutertrei. OVEY was the curator of the British Museum (Natural History) when he published his paper (op. cit.), and it is to be expected that he would not misinterpret BRADY's species concept of "Globigerina dutertrei". Considering the fact that "Globigerina dutertrei" of OveY occurs with typical Globigerina pachyderma and with the intermediate forms, OvEY's form can not be a Globorotalia (Turborotalia). It seems to the present writer that the statements of BANNER \& BLOW on BRADY's and OVEY's forms may be erroneous. They also have designated lectotype of Globigerina eggeri RHUMBLER and say that the species is distinguished from $G_{0}$. dutertrei D'ORBIGNY by its consistently larger tests with more numerous and less appressed chambers in the last whorl. However, the present writer believes that typical Go eggeri is the adult form of $G$. dutertrei and $G$. eggeri becomes a synonym of $G$. dutertrei, while "G. dutertrei" of OvEY and perhaps of BRADY is G. pachyderma (EHRENBERG).

Globigerina pachyderma was originally described from Recent sediment $(1,000$ fathoms) in Davis Strait by EHRENBERG in 1861. BRADY (1884, p. 600) could not find this species in the plankton-net samples of the Challenger Collections. MURRAY $(1897$, p. 20,$21 ; 1913$, p. 165) considered this species to be planktonic, but Heron-Alten \& EARLAND $(1922$, p. 35, 36) pointed out that MuRRaY's statement was not based on definite evidence. They (op. cit., p. 34) examined eighteen tubes of tow-net samples taken during the British Antarctic (Terra Nova) Expedition. Unfortunately, as all the material had been preserved in formalin, the calcareous tests were dissolved and nothing was left but the protoplasmic bodies of the animals, held together by the delicate chitinous lining of the original shell. They could not find Globigerina pachyderma (EHRENBERG) in these samples and stated (op. cit., p. 35) "The question whether Globigerina pachyderma exists in the pelagic state remains still open to doubt." OvEY (op. cit., p. 65) summarized the previous records and also doubted the pelagic state of the species. Globigerina pachyderma has two characters, each contradictory to the other: (1) massive thickening of the shell-wall which is characteristic of benthonic organisms, (2) very wide geographic distribution in the Arctic and Antarctic Oceans which is characteristic of planktonic organisms. Very recently BRADSHAW $(1959$, p. 36, text-fig. 13) finally found Globigerina pachyderma in plankton-net samples and showed its geographical distribution in the subarctic waters of the North Pacific Ocean. This is the first time the species has been found in a planktonic state.

The results obtained by the present author, as described in the foregoing paragraphs, are: (1) only Globigerina sp. cf. G. bulloides D'ORBIGNY is present in the plankton-net samples, (2) Globigerina pachyderma (EHRENBERG) is pre- 
dominant and Globigerina sp. cf. G. bulloides D'ORBIGNY is very rare in the sediment samples. The results appear to suggest two interpretations: (1) Globigerina pachyderma (EHRENBERG) may occur deeper (than $200 \mathrm{~m}$ ) in the water column, or (2) Globigerina pachyderma (EHRENBERG) may not be planktonic in the region studied, and was deposited in the bottom sediment some time before the present, when the surface water was colder. In a preliminary report (UCHIO, 1959), when BRADSHAw's finding of Globigerina pachyderma (EHRENBERG) in a pelagic state was unknown to the writer, the writer followed the second interpretation, which appears to be supported by the fact that the nine out of eleven sediment samples contain a few glauconite granules indicating rather a slow rate of terrigenous sedimentation. This is to be expected around the ice-covered Antarctica. Thereafter, radiocarbon $\left(\mathrm{C}^{14}\right)$ dating of the calcareous tests of Foraminifera at Station 2, where Globigerina pachyderma (EHRENBERG) occupies about $97 \%$ of total Foraminifera population, has been made by Dr. KIGoshI of the Gakushuin University, Tokyo. The result gives an age of the sediment containing the foraminiferal tests of approximately $5490( \pm 370)$ years, and proves the writer's second interpretation. In calculating the age from the measured counting value of the radioactivity the following fact has been taken into consideration. As radioactivity of $\mathrm{C}^{14}$ has been being generated by the reaction of cosmic radiation with the atmosphere and has been gradually accumulated in the hydrosphere, the radioactivity of marine organisms should be about $2 \%$ higher at present than that of terrestial organisms. The value $2 \%$ is based on extensive data given by Dr. RAFTER (1955) of New Zealand. The method of $\mathrm{C}^{14}$ analysis will be published by Dr. KIGOSHI soon in the Journal of the Chemical Society of Japan.

The first interpretation that Globigerina pachyderma (EHRENBERG) may occur deeper in the water column must be ascertained by future investigation. Even if Globigerina pachyderma (EHRENBERG) is found in a pelagic state in a future detailed survey, it will not be contradictory to the fact that the pre-modern (ca. 5490 years old) sediment is exposed at the bottom of the present ocean in the studied area, providing the productivity of Globigerina pachyderma (EHRENBERG) is small enough not to mask the pre-modern sediment extensively.

\section{SUGGESTIONS FOR FUTURE INVESTIGATIONS}

The following suggestions are given for future investigations to clarify whether or not Globigerina pachyderma (EHRENBERG) is present in a pelagic state in this area:

(1) To occupy more stations for net towing in widely scattered areas and to collect plankton at several different depths at each station in order to determine whether or not there are any restricted vertical distributions of 
species. The samples should be preserved in neutral or slightly alkaline formalin so that the calcareous tests will not be dissolved. Net towing should be done before collecting bottom sediments, because it is not rare to find benthonic organisms in tow samples. These benthonic specimens are derived either from the washing of dredged material just before the net tow was made, or from wave action if the net was in shallow water.

(2) To collect bottom sediments at many different places and preserve them in neutralized or slightly alkaline formalin to keep the calcareous tests undissolved. The rose Bengal staining technique described by WALTON (1952) should be applied to these samples to distinguish living from dead specimens. The presence or absence of living Globigerina pachyderma (EHRENBERG) in the sediments will prove indirectly whether the species is benthonic or planktonic.

\section{REFERENCES}

BANNER, F.T. \& BLOW, W.H. 1960. Some primary types of species belonging to the superfamily Globigerinaceae. Contr. Cushman Found. Foram. Res., vol. 11, pt. 1, pp. 1-41, pls. 1-8.

BLow, W.H. 1959. Age, correlation, and biostratigraphy of the Upper Tocuyo (San Lorenzo) and Pozon formations, eastern Falcon, Venezuela. Bull. Amer. Paleontology, vol. 39, no. 178, pp. 67-251, pls. 6-19, 4 maps, 4 charts.

BRADSHAw, J.S. 1959. Ecology of living planktonic Foraminifera in the North and Equatorial Pacific Ocean. Contr. Cushman Found. Foram. Res., vol. 10, pt. 2, pp. 25-64, pls. 6-8, text-figs. $1-43$.

BRADY, H.B. 1884. Report on the Foraminifera dredged by H.M.S. "Challenger" during the years 18731876. Rept. Voy. Challenger, Zoology, vol. 9, 1 vol. text 814 pp., 1 vol. pls. 1-115.

Earland, A., 1933. Foraminifera, Part 2, South Georgia. Discovery Repts., vol. 7, pp. 27-138, pls. $1-7$.

Heron-Allen, E., \& EARland, A. 1922. Foraminifera. British Antarctic ("Terra Nova") Exped,, vol. 6, no. 2 , pp. 25-268.

Murray, J. 1897. On the distribution of the polagic Foraminifera at the surface and the floor of the ocean. Nat. Sci. London, vol. 65, pp. 17-27.

1913. The ocean: A general account of the science of the sea. London, Williams and Norgate, $256 \mathrm{pp}$.

OrbignY, A. D'. 1839. Foraminiferes. In R. de la Sagra, Histoire physique, politique et naturelle de l'Ile de Cuba. Paris, Bertrand, pp. 1-224, (plates published separately).

OvEY, C.D. In WISEMAN, J.D. \& OveY, C.D. 1950. Recent investigations on the deep-sea floor. Proc. Geol. Assoc., London, vol. 61, pt. 1, pp. 28-84, pls. 2-3, text-figs., 3 tables.

Phileger, F.B., Parker, F.L. \& PeIrson, J.F. 1953. North Atlantic Foraminifera. Repts. Swedish Deep-Sea Exped., vol. 7, no. 1, pp. 3-122, pls. 1-12, text-figs. and charts.

Prrie, J.H.H. 1913. Scottish National Antarctic Expedition, 1902-04, Deep sea deposits. Trans. Roy. Soc. Edinburgh, vol. 49, pt. 3, no. 10, pp. 645-686.

RAFTER, T.A. 1955. $C^{14}$ variations. in nature and the effect on radiocarbon dating. New Zealand Journal of Science and Technology, ser. B, vol. 37, pp. 20-38.

Sverdrup, H.U., Johnson, M.S. \& Fleming, R.H. 1946. The oceans. Their physics, chemistry and general biology. Prentice Hall, New York, 1087 pp.

Uchio, T. 1959. Foraminifera assemblages in bottom sediments and in plankton-net samples in the Antarctic Ocean (abstract) (in Japanese), Jour. Geol. Soc. Japan, vol. 65, no. 766, p. 443. 


\section{Planktonic Foraminifera of the Antarctic Ocean}

Uchio, T. 1960. Benthonic Foraminifera of the Antarctic Ocean. Biological Results of the Japanese Antarctic Research Expedition, no. 12, pp. 1-20, a plate, (Spec. Publ. Seto Marine Biological Laboratory).

WALTON, W.R. 1952. Techniques for recognition of living Foraminifera. Contr. Cushman Found. Foram. Res., vol. 3, pt. 2, pp. 56-60. 


\section{Plate I}

Figs. 1-3. Globigerina pachyderma (EHRENBERG).

in sediment sample at Station 2 ( $c a$. 5,500 years old).

Fig. 1 .................................................... $\times 32$

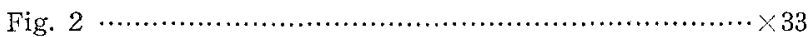

Small specimens are typical G. pachyderma.

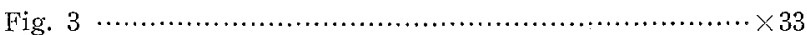

Large specimens has been considered " $G$. dutertrei"

( $G$. dutertrei of OvEY, ? BRADY, not D'ORBIGNY), but are adult forms of $G$. pachyderma.

Figs. 4-6. Globigerina sp. cf. G. bulloides D'OrBIGNY.

in plankton-net sample at Station B.

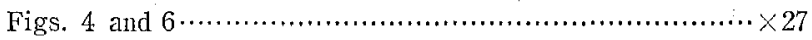

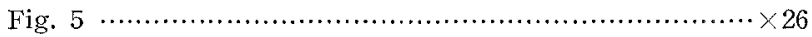


Plate I
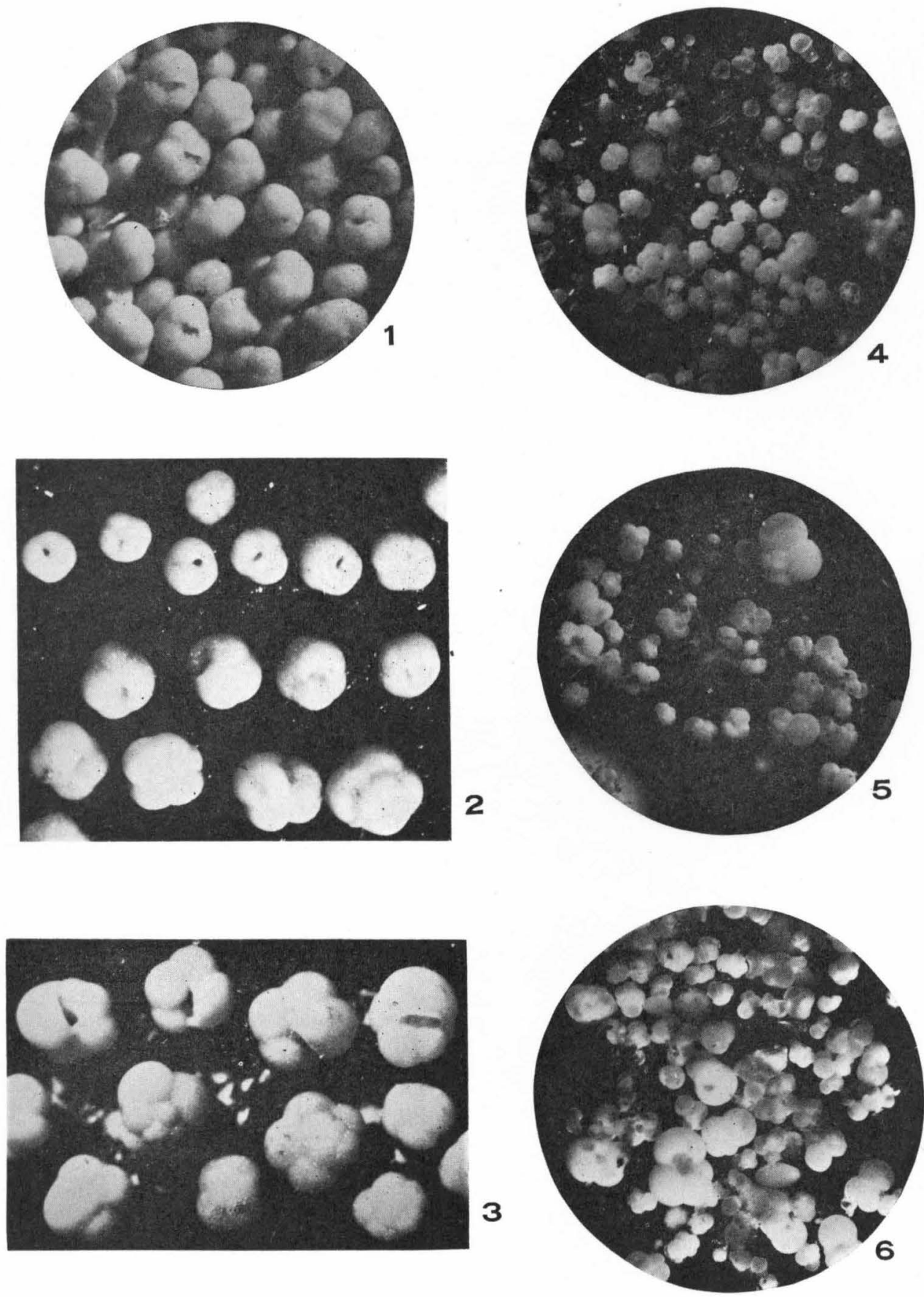


\section{BIOLOGICAL RESULTS}

OF

THE JAPANESE ANTARCTIC RESEARCH EXPEDITION

1. Tanita, Senji: Sponges. 1959.

$¥ 50$

2. NAKASEKo, Kojiro: On Superfamily Liosphaericae (Radiolaria) from sediments in the sea near Antarctica (On Radiolaria from sediments in the sea near Antarctica. Part 1). 1959.

150

3. Hirano, Minoru: Notes on some algae from the Antarctic collected by the Japanese Antarctic Research Expedition. 1959.

$¥ 150$

4. Hatai, Kotora: A new rhynchonellid (Brachiopoda) from Antarctica. 1959. $\quad 50$

5. TokiokA, Takasi : Amaroucium erythraeum Michaelsen, a compound ascidian from the Cape Province. 1959. $\quad ¥ 50$

6. Yosir, Riozo: Collembolan fauna of the Cape Province, with special reference to the genus Seira Lubbock. 1959.

$¥ 150$

7. Gamô, Sigeo: On a cumacean Crustacea (Diastylis corniculatus Hale) obtained by the Second Japanese Antarctic Research Expedition (1957-58). 1959. $¥ 50$

8. Utinomi, Huzio: Pycnogonida of the Japanese Antarctic Research Expeditions 1956-1958. 1959.

$¥ 100$

9. Matsubara, Kiyomatsu and Iwai, Tamotsu: Fishes. 1959 .

10. Tanaka, Otohiko: Pelagic Copepoda. 1960 . 700

11. Uchio, Takayasu: Planktonic Foraminifera of the Antarctic Ocean. 1960 . 100 